\title{
Understanding Pacific Northwest (U.S.) mountain climbers' motivations: Mount Baker, Washington, and Mount Hood, Oregon
}

\author{
Robert C. Burns, Teri Chuprinko \& Mary E. Allen
}

Keywords: outdoor recreation, motivations, mountaineering, wilderness areas

\section{Abstract}

Mountaineers are motivated to climb for myriad reasons, both intrinsic and extrinsic. This study examined the motivations of recreationists to climb on Mt. Hood, Oregon, and Mt. Baker, Washington, and how these motivations varied between mountain wilderness locations. Data were collected through onsite, mail and online surveys at two separate mountain settings ( $N=865)$. The survey instrument included 22 motivation items designed to measure seven motivational domains. The results found that the primary motivations of all climbers focused on the aesthetic quality of mountain locations, physical fitness, escaping normal routines, and gaining a sense of accomplishment. An independent samples t-test revealed differences in the motivations of climbers at Mt. Hood versus Mt. Baker, while a Linear regression tested the role of motivation on participation. Most notably, climbers at Mt. Baker gave greater importance to recognition and catharsis as motivations. These findings showed that while recreationists climb for many of the same reasons, they are motivated to climb for different experiences offered by different alpine settings. The motivation regression model was a weak predictor of participation. This information on motivations could assist federal land management agencies in gaining a better understanding of how to balance climbers' needs with preserving high-altitude environments.

\section{Profile}

Protected area

\section{Mt. Hood National}

Forest and Mt. Baker-

Snoqualmie National

Forest

Country

\section{U.S}

\section{Introduction}

Mountaineering takes place in some of the wildest, most pristine environments in the world, and this reality has created a certain level of stewardship and environmental ethics in the mountaineering community as a whole. Alpine environments offer scenic beauty, unique natural formations and opportunities to experience adventure activities in remote wilderness environments (Williams \& Soutar 2005). Many of the mountains considered popular climbing destinations in North America are managed by federal land management agencies such as the United States Forest Service (USFS) and the National Park Service. This is especially true in the Pacific Northwest states of Oregon and Washington, where many of the mountain peaks fall into areas classed as Wilderness. These wilderness areas, which make up the National Wilderness Preservation System, are federally owned areas designated by U.S. Congress under the Wilderness Act of 1964 (16 U.S.C. 1131-1136).

Wilderness areas are administered for both the use and the protection of natural resources, but to balance these two goals is a challenge (Frissel \& Stankey 1972; Manning 2001, 2007). Implicit in this dual mission is the quality of the visitor experience and the attributes which attract people to visit wilderness areas. For instance, wilderness areas provide a primitive and unconfined type of recreation, as well as opportunities for solitude in nature. At the same time, the quality of wilderness recreation experiences depends on the protec- tion of natural resources. As the population grows, this becomes more difficult and recreation management in wilderness areas becomes increasingly challenging. To manage mountain wilderness areas properly, with the appropriate balance between meeting climbers' needs and preserving wilderness environments, user motivations are sought. Understanding the motivations or the reasons why recreationists participate in mountaineering is important in determining the significance of recreation in wilderness areas, and the desired social and biophysical conditions for which mountain areas should be managed (Graefe et al. 2000).

The degree of protected status is the same across the two settings in our study - both Mount Baker and Mount Hood include terrain types ranging from front-country to undeveloped back-country, and both include Wilderness areas. To prevent overcrowding and conflict, the United States Forest Service (USFS) limits the number of days annually that guiding companies can operate. These management decisions are made in response to the number of users on the two mountains and whether those use-levels are consistent with the standards set by regulations (Chuprinko 2012). Such decisions have become more critical, as participation rates in mountaineering and other adventure activities have increased by over 25 percent since 2009 (Outdoor Industry Foundation 2018). To better understand the varying levels of use and why different use patterns may occur, this study examined the underlying motivations of recreational mountaineers at Mount Baker, Washington, and Mount Hood, Oregon. 
Recreational mountaineering is an extremely demanding physical and psychological activity, taking its participants into some of the most daunting, harshest and most pristine environments in the world. Like other types of adventure recreation activities, mountaineering is fraught with elements of physical, emotional or psychological risk and potential danger (Ewert \& Vernon 2013). Mountaineering involves close interactions with the natural environment and often entails an uncertain outcome (Ewert et al. 2013). Many of the mountains that attract climbers are so grand in scale that they create their own highly unpredictable weather patterns, yet weather is only one of the challenges that climbers face. The risks of climbing mountains include injury and death; the activity can also present climbers with dangerous situations such as crevasse crossing, ice fall and avalanches (Bowley 2011; Mei-Dan et al. 2013; Monasterio \& Cloninger 2019). Thus, mountaineering is an activity that requires specialist skills, mental preparation, control, physical conditioning and a keen sense of judgement (Breed \& Gurubacharya 2016; Buckley 2012).

\section{Theoretical background}

\section{Motivations}

Motivation is a central concept in the attempt to understand why people choose to participate in a recreation activity such as mountain climbing (Iso-Ahola 1980). Behaviours are motivated by some sort of goal, benefit or need, and a person may have multiple motivations behind a single behaviour. For example, both good health and a positive body image may be strong motivations for a person who is dieting. In outdoor recreation research, analysing motivations started with Maslow's Hierarchy of Human Needs (1943), namely physiological, safety, love / belonging, self-esteem and self-actualization needs. These needs still form the basis of research into motivations. The social and biophysical contexts of mountaineering present a diversity of needs or reasons why someone would climb a particular mountain area. As with any other recreation activity, mountaineers climb for myriad reasons, both intrinsic and extrinsic (Ewert 1985, 1990, 1994; Pomfret 2006). Intrinsic motivation refers to doing something because it is inherently interesting or enjoyable, rather than for some separable outcome (Ryan \& Deci 2000). Previous research has found that as individuals become more engaged in a recreation activity, motivations for participation will become more in line with internal motivations (Buckley 2012; Ewert \& Hollenhorst 1989). Extrinsic motivation refers to doing something because it leads to a separable outcome (Ryan \& Deci 2000). Extrinsic motivations vary considerably in their relative autonomy and are more likely to emerge from factors outside the individual, such as other people, normative influence, or pressure by friends or family to participate. Because of the inherent risk involved with adventure recreation activi- ties, participation tends to be less driven by extrinsic motives (Delle Fave et al. 2003).

Multiple motivations have long been an area of study in outdoor recreation. Some early theories in the study of multiple motivations have included motives of compensation, familiarity, surplus energy, relaxation and catharsis (Manning 1999). (For explanations of catharsis and other items, see Table 1 below.) Studies have also attempted to categorize recreation motivations by their methodology. Bultena and Taves (1961) grouped their motivation factors into five categories: wilderness as a location for sport and play, wilderness as fascination, wilderness as sanctuary, wilderness as heritage, and wilderness as personal gratification. Knopf et al. (1983) examined boaters and floaters on eleven different rivers using the categories friendship, escape, learning, family, simplicity, social power and social contact. Over subsequent decades, motives have been studied more systematically (Roggenbuck \& Driver 2000). These later studies suggest that there are common motives for visiting wilderness areas, such as solitude and experiencing nature, but that not all motives are shared (Stankey \& Schreyer 1987).

Traditionally, recreation motivations and decisions were based on an activity-centred approach (Manning 1999). Since Driver and Toucher (1970), researchers have investigated why people choose certain activities over others, and the benefits they seek from choosing a particular activity. This type of inquiry has studied recreation participation from a behavioural approach. The Recreation Experience Preference (REP) Scales (Driver 1983) were developed as a result of such studies. The goal of REP Scales was to comprehensively measure the concepts of interests while being reliable, valid and practical from a management standpoint (Manfredo et al. 1996). The REP Scales are made up of nineteen domains or general motivation categories (Manning 1999); specific motivation items, or scales, are listed under each domain; in total, there are 234 scale items. Core statements were then developed under each scale and act as prompts for potential survey questions (Driver 1983). Since it would be overwhelming to ask recreation participants in a survey about all 234 motivational items, researchers have conducted empirical studies to pinpoint the exact motivational drivers behind certain recreation activities (Manfredo et al. 1996). REP Scales have been adapted to and utilized in several studies examining adventure activities, such as whitewater rafting (Fluker \& Turner 2000) and mountaineering (Ewert 1985, 1987, 1994; Pomfret 2006). More recently, the REP Scale has been revised to understand female recreationists (Borrie et al. 2000; Covelli 2006; Metcalf et al. 2015) and hikers in wilderness areas (Garms et al. 2017; Raadik et al. 2010).

\section{Mountaineering motivations}

Previous research has investigated the motivations of climbers in association with specific alpine environments (Ewert 1990, 1994) and skill level (Ewert 1985, 


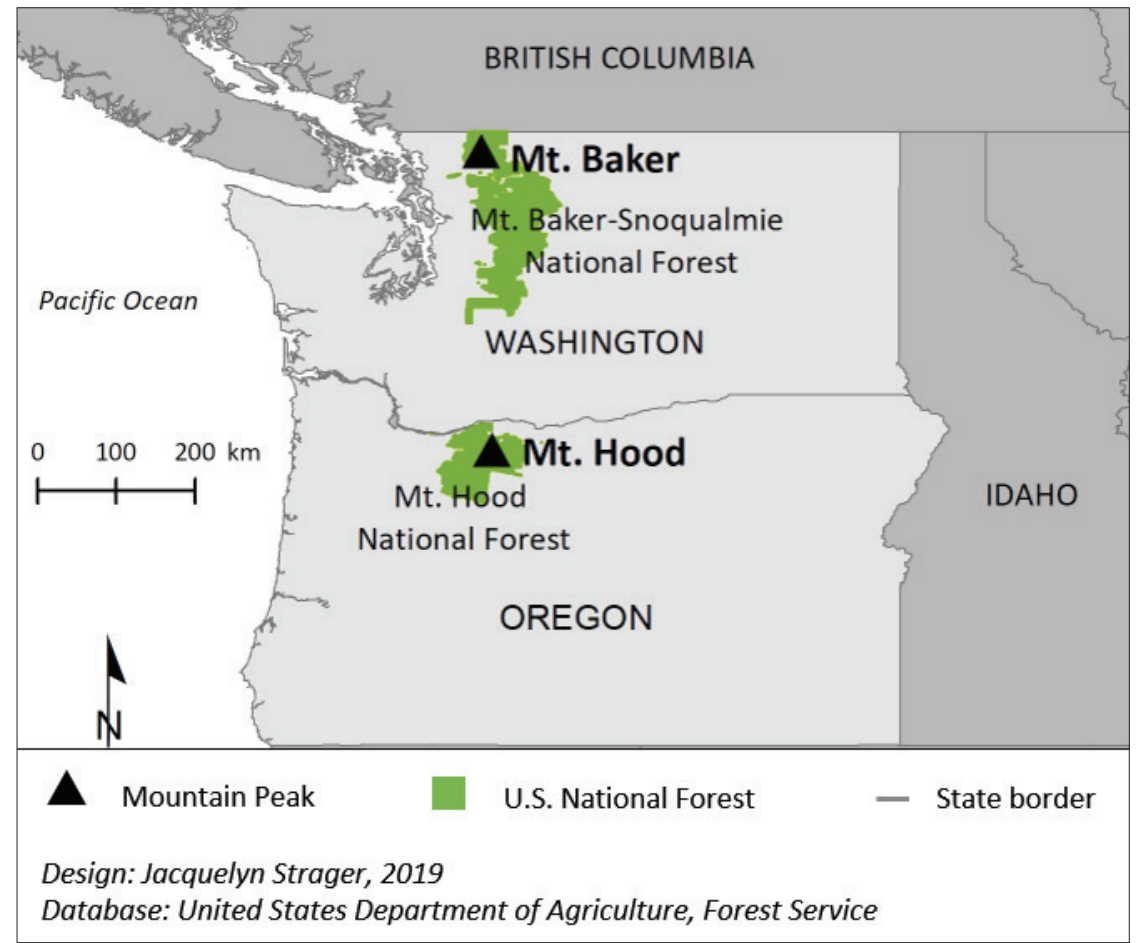

Figure 1 - Map of Mt. Hood, Oregon, and Mt. Baker, Washington (map credit: US Forest Service).

1994; Ewert et al. 2013; Pomfret 2006). Studies have shown that mountaineers are intrinsically motivated to scale mountains such as Mt. Rainer or Mt. McKinley for catharsis, locus of control and creativity, and personal growth (Smith et al. 2016). Mountain climbers in the Himalayas were motivated by senses of confidence, challenge and risk (Delle Fave et al. 2003). Selfdetermination, therefore, is a major motivating factor for participation in mountain climbing, requiring the ability to manage one's fear and act competently within an environment over which one must exert control (Kiewa 2001). To participate in mountaineering, one must often climb with a small group of dedicated, trustworthy climbing partners. Thus, camaraderie and bond-strengthening can also be characteristic motivations of the recreational mountaineer (Will 2016). In a study of mountaineers in the French Alps, mountaineering was an important part of their lifestyles and gave them a sense of identity (Pomfret 2011). Their previous levels of experience in mountaineering encouraged future involvement in the activity for the purposes of developing skills and enhancing social bonds with other mountaineers.

It has also been suggested that mountaineering motivations may vary according to the mountain environment, as seen in a study of climbing motivations at Mount St. Helens (Ewert 1990), the terrain of which was dramatically altered by the catastrophic 1980 eruption. This unique environment offered visitors and climbers a window into the aftermath of the eruption and recovery of the surrounding environment. The results from the study suggested that after the eruption, changes occurred in visitors' motivations to climb Mount St. Helens. The post-eruption climbers rated to experience the volcano and to observe natural settings far higher than traditional mountaineering motivations (Ewert 1990).

Recreational mountaineers have shown a variation in motivations according to climbing outcome. Ewert (1994) interviewed climbers on Mt. McKinley, Alaska, and found that those who had successfully climbed to the summit expressed items such as challenge, accomplishment and excitement as their main motivators. On the other hand, climbers who were forced to turn back, without making it to the summit, expressed items such as being outdoors and viewing scenery as their main motivators. Thus, motivations to participate in mountain climbing are diverse and linked to multiple types of motives, such as sensation-seeking, self-image, or social or aesthetic motives (Ewert et al. 2013).

Based on the literature and past research findings, the purpose of this study was to examine the motivations of recreationists to participate in mountaineering on Mt. Hood and Mt. Baker. More specifically, this study had three main research questions:

R1: Do climbers on Mt. Hood and Mt. Baker vary in socio-demographic characteristics?

R2: Are there differences in the motivations of mountain climbers on Mt. Hood and Mt. Baker?

R3: Are mountaineering motivations predictors of climbing participation on Mt. Hood and Mt. Baker? 
Table 1 - Seven mountaineering motivation domains and 22 motivation items.

\begin{tabular}{|l|l|l|}
\hline $\begin{array}{l}\text { Motivation } \\
\text { Domains }\end{array}$ & Motivation Items & References \\
\hline $\begin{array}{l}\text { Chal- } \\
\text { lenge / } \\
\text { Risk }\end{array}$ & $\begin{array}{l}\text { To prove to yourself that you can } \\
\text { do it } \\
\text { For excitement and exhilaration } \\
\text { To feel a sense of accomplishment } \\
\text { For the challenge and risk }\end{array}$ & $\begin{array}{l}\text { Ewert 1985, } \\
\text { 1987; Fluker } \\
\text { \& Turner } \\
2000 ; \text { Pom- } \\
\text { fret 2006 }\end{array}$ \\
\hline Catharsis & $\begin{array}{l}\text { To slow your mind } \\
\text { To find peace and quiet } \\
\text { To relieve stress and anxiety } \\
\text { To get away from your daily routine }\end{array}$ & $\begin{array}{l}\text { Ewert 1985, } \\
1987 ; \text { Pom- } \\
\text { fret 2006 }\end{array}$ \\
\hline $\begin{array}{l}\text { Recogni- } \\
\text { tion }\end{array}$ & $\begin{array}{l}\text { To prove to others that you can do it } \\
\text { To be known as a mountaineer }\end{array}$ & $\begin{array}{l}\text { Ewert 1985, } \\
1987 ; \text { Pom- } \\
\text { fret 2006 }\end{array}$ \\
\hline Creativity & $\begin{array}{l}\text { To use your mind } \\
\text { To help others } \\
\text { To climb a new route } \\
\text { To think about new ways to ap- } \\
\text { proach a climb }\end{array}$ & $\begin{array}{l}\text { Ewert 1985, } \\
1987 ; \text { Pom- } \\
\text { fret 2006 }\end{array}$ \\
\hline $\begin{array}{l}\text { Locus of } \\
\text { Control }\end{array}$ & $\begin{array}{l}\text { To form new friendships } \\
\text { To gain control of the situation } \\
\text { To develop your skills }\end{array}$ & $\begin{array}{l}\text { Ewert 1985, } \\
1987 ; \text { Pom- } \\
\text { fret 2006 }\end{array}$ \\
\hline $\begin{array}{l}\text { Physical } \\
\text { Setting }\end{array}$ & $\begin{array}{l}\text { To be outdoors } \\
\text { To view the scenery }\end{array}$ & $\begin{array}{l}\text { Ewert 1985, } \\
1987 ; \text { Pom- } \\
\text { fret 2006 }\end{array}$ \\
\hline Other & $\begin{array}{l}\text { Because it is close to home } \text { with friends and family } \\
\text { Tornett 2004 }\end{array}$ & \\
\hline
\end{tabular}

\section{Methodology}

\section{Study areas}

Mt. Hood is located in the Mt. Hood National Forest (Region 6 of the U.S. Forest Service) in northwestern Oregon state, close to the border of Washington state (Figure 1). Mt. Hood is Oregon's highest summit at 3426 metres and is a dormant volcano with eleven active glaciers (USDA 2019). The climbing season is generally from April to mid-June, due to melting snow and rock-fall hazards later in the season (USDA 2019). More than 10000 climbers a year seek the top of Mt. Hood, making its summit the most visited snow-covered peak in the United States (USDA 2019). The ease of access to this mountain makes it a popular destination for climbers of all skill levels from around the country and globe. Climbers are required year-round to have a Wilderness permit in their possession when on the South Side climbing route of Mt. Hood; to enter the Wilderness area, a permit is required during May to October.

Mt. Baker is located at the extreme northern extent of the Mt. Baker-Snoqualmie National Forest in Washington state and is also within Region 6 of the USFS (Figure 1). The forest is approximately 40 miles east of the Seattle metropolitan area. Mt. Baker is an active glaciated volcano in the Cascade Mountains and stands at 3286 metres, making it the fourth highest summit in Washington (US Forest Service 2006). The mountain is covered by thirteen glaciers and is a popular climbing destination, accessible by more than fifty miles of trail. Mt. Baker lies in two congressionally designated areas: the Mt. Baker Wilderness and the
Table 2 - Socio-demographic profile of survey respondents.

\begin{tabular}{|l|c|c|}
\hline Socio-demographic profile & $\begin{array}{c}\text { Frequency } \\
\text { (N) }\end{array}$ & $\begin{array}{c}\text { Valid Percent } \\
\text { (\%) }\end{array}$ \\
\hline Gender & 113 & 13.5 \\
\hline Female & 721 & 86.5 \\
\hline Male \\
\hline Age Recoded \\
\hline 30 or younger \\
\hline 31-50 & 220 & 26.2 \\
\hline 51 and over & 422 & 50.2 \\
\hline Education & 198 & 23.6 \\
\hline High School or College & 147 & 17.5 \\
\hline Bachelor's or Associate's degree & 370 & 44.1 \\
\hline Master's degree & 222 & 26.5 \\
\hline $\begin{array}{l}\text { Ph.D., M.D., J.D. or Professional } \\
\text { degree }\end{array}$ & 100 & 11.9 \\
\hline Citizenship & 791 & 94.8 \\
\hline U.S. Citizen & 43 & 5.2 \\
\hline From another country
\end{tabular}

Mt. Baker National Recreation Area. The majority of Mt. Baker is in Wilderness, with the National Recreation Area encompassing the south slope. The mountain offers a variety of approaches of varying degrees of technical difficulty for would-be climbers. Some of the more popular routes are via the Coleman Glacier and the Easton Glacier. All routes to the summit are technical climbs on glaciers, and necessitate experience, knowledge of crevasse rescue techniques and safe climbing habits.

\section{Survey instrument}

The survey instrument included questions that were designed to measure seven domains of mountaineering motivations: 1) challenge/ risk, 2) catharsis, 3) recognition, 4) creativity, 5) locus of control, 6) physical setting, and 7) other motivations (Table 1). These domains were measured by a total of 22 motivation items, which were adapted from previous mountaineering studies (Ewert 1985; Pomfret 2006; Barnett 2004). Each motivation item was rated on a five-point Likert scale ranging from not at all important $($ score $=1)$ to extremely important $($ score $=5)$. Basic demographics, such as gender, age, race, ethnicity, income and place of residence, included in the original survey instrument were also examined for the purpose of this study.

\section{Data collection}

Three survey methods were used for data collection, including a mail-back survey, an online survey and on-site interviews. All three surveys were identical in design and the questions asked. The mail survey was distributed to potential respondents following the methodology outlined by Dillman et al. (2014), which uses personalization and repeated contacts to increase the likelihood that an individual will complete and return the survey. Each study participant was sent a hand-addressed packet of survey materials which in- 
Table 3 - Percentage distribution and mean importance of mountaineering motivations.

\begin{tabular}{|l|r|r|r|r|r|r|r|}
\hline Motivation Item & $\begin{array}{l}\text { Not } \\
\text { Important } \\
\text { (1) }\end{array}$ & $\begin{array}{l}\text { Somewhat } \\
\text { Important } \\
\text { (2) }\end{array}$ & $\begin{array}{l}\text { Very } \\
\text { Important } \\
\text { (3) }\end{array}$ & $\begin{array}{l}\text { Moderately } \\
\text { Important } \\
\text { (4) }\end{array}$ & $\begin{array}{l}\text { Extremely } \\
\text { Important } \\
\text { (5) }\end{array}$ & Mean \\
\hline Challenge / Risk & 8.9 & 12.7 & 17.5 & 24.7 & 36.2 & 3.66 \\
\hline a. To prove you can do it & 3.6 & 9.9 & 18.9 & 35.1 & 32.4 & 3.83 \\
\hline b. Excitement and exhilaration & 1.9 & 5.0 & 12.0 & 33.3 & 47.8 & 4.20 \\
\hline c. To feel a sense of accomplishment & 5.9 & 12.4 & 23.0 & 32.4 & 26.3 & 3.61 \\
\hline d. For the challenge and risk \\
\hline Catharsis \\
\hline e. To slow your mind \\
\hline f. To find peace and quiet \\
\hline g. To relieve stress and anxiety
\end{tabular}

cluded a cover letter, a survey and a U.S. postage-paid business reply envelope (Dillman et al. 2014). The online survey followed the same schedule. Finally, onsite surveys were conducted with climbers who were intercepted at Mt. Hood and Mt. Baker from 28 May to 8 August 2010.

\section{Results}

\section{Sample profile}

The data collection for this study yielded a total of 865 completed surveys, with 485 surveys obtained from Mt. Hood climbers and 380 from Mt. Baker climbers. Of this total, 342 were completed via mail, 208 online and 315 on site. The socio-demographic profile of the respondents included their gender, age, education, race and ethnicity (see Table 2). The results showed that a majority $(86.5 \%)$ of the climbers were male. Half of the climbers were aged $31-50$ years old, and just over a quarter $(26.2 \%)$ were 30 or younger. $23.6 \%$ of the climbers were over the age of 50 . Overall, the sample was highly educated, with over four-fifths $(82.5 \%)$ having a Bachelor's degree or higher. A considerable number $(11.9 \%)$ of the climbers indicated having a Ph.D., M.D., J.D. or equivalent, and around a quarter $(26.5 \%)$ had a Master's degree. Less than one-fifth $(17.5 \%)$ of the total sample had an educational attainment level of anything below a Bachelor's or Associate's degree.

Mountaineering motivations

A total of 22 motivation items from seven domains were presented to the climbers, who were instructed to rate each item on a scale of 1 (not at all important) to 5 (extremely important) (see Table 3). Of all the motivation items evaluated, the most important to climbers were the two items from the Physical Setting domain: to be outdoors (mean $=4.62)$ and to view scenery (mean $=4.52)$. The majority of climbers rated these two items as very important to extremely important motives for climbing both Mt. Hood and Mt. Baker. Items from the Catharsis and Challenge / Risk domains were also quite important to the respondents. Over four-fifths $(82.5 \%)$ of the climbers indicated that to get away from your daily routine (a Catharsis item) was very important to extremely important. Additionally, a large segment $(81.1 \%)$ of the sample rated to feel a sense of accomplishment (a Challenge / Risk item) in the same manner.

While some motivations were important to some of the climbers on Mt. Hood and Mt. Baker, not all were equally important. Overall, the two Recognition domain items, to prove to others that you can do it $($ mean $=2.06)$ and to be known as a mountaineer 
Table 4 - Mean differences in mountaineering motivations of climbers on Mt. Hood and Mt. Baker.

\begin{tabular}{|c|c|c|c|}
\hline Motivation Item & Mt. Baker Mean ${ }^{a}$ & Mt. Hood Mean ${ }^{a}$ & $t$ \\
\hline \multicolumn{4}{|l|}{ Challenge/Risk } \\
\hline a. To prove to yourself that you can do it & 3.76 & 3.58 & 3.278 \\
\hline b. Excitement and exhilaration & 3.93 & 3.75 & 2.583 \\
\hline c. To feel a sense of accomplishment & 4.23 & 4.18 & 2.331 \\
\hline d. For the challenge and risk & 3.72 & 3.52 & 0.478 \\
\hline \multicolumn{4}{|l|}{ Catharsis } \\
\hline e. To slow your mind & 3.60 & 3.36 & $6.699 * *$ \\
\hline f. To find peace and quiet & 3.86 & 3.65 & 2.723 \\
\hline g. To relieve stress and anxiety & 3.79 & 3.58 & $5.680^{*}$ \\
\hline h. To get away from your daily routine & 4.28 & 4.17 & 0.024 \\
\hline \multicolumn{4}{|l|}{ Recognition } \\
\hline i. To prove to others that you can do it & 2.08 & 2.05 & 0.185 \\
\hline j. To be known as a mountaineer & 2.22 & 1.96 & $19.558^{* * *}$ \\
\hline \multicolumn{4}{|l|}{ Creativity } \\
\hline k. To use your mind & 3.81 & 3.59 & 1.786 \\
\hline I. To help others & 2.90 & 2.73 & 0.204 \\
\hline m. To climb a new route & 3.20 & 2.85 & 1.480 \\
\hline n. To think about new ways to approach a climb & 3.14 & 2.87 & $6.056^{*}$ \\
\hline \multicolumn{4}{|l|}{ Locus of Control } \\
\hline o. To form new friendships & 2.93 & 2.73 & 2.079 \\
\hline p. To gain control of the situation & 2.95 & 2.54 & 1.523 \\
\hline q. To develop your skills & 4.07 & 3.96 & 2.551 \\
\hline \multicolumn{4}{|l|}{ Physical Setting } \\
\hline r. To be outdoors & 4.66 & 4.59 & $5.028^{*}$ \\
\hline s. To view scenery & 4.54 & 4.51 & 0.277 \\
\hline \multicolumn{4}{|l|}{ Other } \\
\hline t. Because it is close to home & 2.44 & 2.86 & 0.097 \\
\hline u. For physical exercise & 4.49 & 4.36 & $3.964^{*}$ \\
\hline v. To be with friends and family & 3.75 & 3.52 & 2.437 \\
\hline
\end{tabular}

${ }^{a} 1=$ not important, $2=$ somewhat important, $3=$ very important, $4=$ moderately important,

$5=$ extremely important; ${ }^{*} p \leq 0.05$, ** $p \leq 0.01$, *** $p \leq 0.001$.

(mean $=2.08)$, were the least important motivation items to the sample of climbers. Although most of the climbers rated these two items as not at all important to somewhat important, a small proportion (nearly $15 \%$ ) of the respondents indicated that these were important motives for scaling the mountains.

The social motivations were less important to the respondents than some of the other items. To help others (mean $=2.81$ ), a Creativity domain item, was rated as not at all important to somewhat important by $41.0 \%$ of the sample and moderately important by another $29.2 \%$. Similarly, to form new friendships (mean $=2.82$ ), a Locus of Control domain item, was rated as not at all important to somewhat important by $40.4 \%$ of the sample and moderately important by another $29.2 \%$. However, to be with friends or family (mean $=3.62$ ), a domain item adapted from various studies, was rated much higher than other social motives, with $61.4 \%$ of the sample rating it very important or extremely important.

Two other items from the Locus of Control and Creativity domains were also rated lower than the rest of the mountaineering motivations. To gain control of the situation (mean $=2.72$ ) was rated moderately important or lower by nearly three-quarters of the en- tire sample $(71.6 \%)$. Furthermore, to think about new ways to approach a climb (mean $=2.99)$ was deemed moderately important or less by $63.9 \%$ of the sample.

\section{Comparison of motivations at Mt. Hood versus Mt. Baker}

An independent samples t-test was utilized to analyse potential differences in the motivations of climbers on Mt. Hood versus those on Mt. Baker (Table 4). Of the 22 motivation items, 7 showed statistically significant differences $(\mathrm{p}=.05 ; 95 \% \mathrm{CI})$. To be outdoors $(t=5.03 ; \mathrm{p} \leq .05)$, from Physical Setting, was given higher importance on Mt. Baker (mean = 4.66) than Mt. Hood (mean =4.59). Similarly, for Physical Exercise $(t=3.96 ; \mathrm{p} \leq .05)$ was given a higher mean importance score by $\mathrm{Mt}$. Baker respondents $($ mean $=4.49)$ than by Mt. Hood respondents (mean = 4.36).

Two of the four items in the Catharsis domain revealed statistically significant differences between the two mountains. First, to slow your mind was an item that was slightly more important to climbers on Mt. Baker (mean = 3.60) than to those on Mt. Hood $($ mean $=3.36) \quad(t=6.70 ; \mathrm{p} \leq .01)$. Another Catharsis item, to relieve stress and anxiety $(t=5.68 ; \mathrm{p} \leq .05)$, also scored higher on Mt. Baker than on Mt. Hood. 
Table 5 - Results of Linear Regression of Motivations and Climbing Participation.

\begin{tabular}{|l|l|r|r|}
\hline Motivation Domain & Motivation Item & \multicolumn{1}{c|}{ r } & \multicolumn{1}{c|}{ Beta } \\
\hline Challenge/Risk & To prove to yourself that you can do it & -.227 & -.097 \\
\hline & Excitement and exhilaration & -.177 & .000 \\
\hline & To feel a sense of accomplishment & -.196 & -.081 \\
\hline & For challenge and risk & -.174 & .002 \\
\hline & To slow your mind & -.018 & -.101 \\
\hline & To find peace and quiet & $.066^{*}$ & $.112^{* *}$ \\
\hline & To relieve stress and anxiety & -.009 & .025 \\
\hline & To get away from your daily routine & -.016 & -.012 \\
\hline Recognition & To prove to others that you can do it & -.119 & .009 \\
\hline & To be known as a mountaineer & -.155 & -.031 \\
\hline Creativity & To use your mind & -.039 & $.132^{* * *}$ \\
\hline & To help others & $.185^{* * *}$ & $.097^{* * *}$ \\
\hline & To climb a new route & -.121 & -.071 \\
\hline & To think about new ways to approach a climb & -.072 & .070 \\
\hline Locus of Control & To form new friendships & $-.023^{*}$ & $-.107^{*}$ \\
\hline & To gain control of the situation & $-.141^{* * *}$ & $-.102^{*}$ \\
\hline & To develop your skills & $-.215^{* * *}$ & $-.210^{* * *}$ \\
\hline Physical setting & To be outdoors & .000 & .017 \\
\hline & To view scenery & .009 & .001 \\
\hline Other & Because it is close to home & $.220^{* * *}$ & $.157^{* * *}$ \\
\hline & For physical exercise & $.059^{*}$ & $.097^{*}$ \\
\hline & To be with friends and family & .005 & -.021 \\
\hline & \multicolumn{1}{|c}{ Adjusted R Square $=0.142^{* * *}$} & & \\
\hline
\end{tabular}

${ }^{*} p \leq .05 ;{ }^{* *} p \leq .01 ; *^{* *} p \leq .001$

The remaining significant values also showed that the motivation items were more important on $\mathrm{Mt}$. Baker than Mt. Hood. To be known as a mountaineer from the Recognition domain was rated far higher by the climbers on Mt. Baker (mean =2.22) than those on Mt. Hood (mean $=1.96, \mathrm{t}=19.56, \mathrm{p} \leq .001)$. To think about new ways to approach a climb was more important to Mt. Baker climbers (mean=3.14) than to climbers at Mt. Hood (mean $=2.87, \mathrm{t}=6.06, \mathrm{p} \leq .05)$.

Mountaineering motivations as predictors of climbing participation

To understand the impact of motivations on participation, a Linear Regression model was developed. The motivation items were the independent variables; the participation question (number of times participating) was the dependent variable. Only one of the participation questions produced significant results (see Table 5). The number of times the respondents had climbed the two peaks explained about 14 percent of the variance associated with mountaineering motivations (Adjusted R-Square $=0.142 ; \mathrm{F}=6.293$ ).

Of the full set of 22 motivation items, seven items proved to be valid predictors of recreational mountaineering participation. These motivation items were spread across four of the seven domains. First, to find peace and quiet from the Catharsis domain produced significant results $(\mathrm{r}=.066$; Beta $=.112 ; \mathrm{p} \leq .01)$, showing a positive correlation with mountaineering participation. Both close to home $(r=.220$; Beta $=.157)$ and for physical exercise $(r=.059$; Beta $=.097)$ from the
Other domain were also shown to have a positive correlation to climbing participation.

The Creativity domain yielded two items with significant correlations between motivations and mountaineering participation. The first item, to use your mind, showed a negative correlation to mountaineering participation $(\mathrm{r}=-.039 ;$ Beta $=.132 ; \mathrm{p} \leq .001)$. On the other hand, to help others showed a positive correlation to climbing participation $(r=.185$; Beta $=.097$; $\mathrm{p} \leq .001)$.

The Locus of Control domain items were all significant according to the regression model results. The three items all showed a negative correlation between each mountaineering motivation item and actual climbing participation on the two peaks. The item with the strongest relationship was to develop your skills $(\mathrm{r}=-.215$; Beta $=-.210 ; \mathrm{p} \leq .001)$. The next item to show a correlation between motivations and participation was to gain control of the situation $(\mathrm{r}=-.141 ;$ Beta $=-.102 ; \mathrm{p} \leq .05)$. Lastly, the item with the weakest relationship was to form new friendships $(\mathrm{r}=-.023 ;$ Beta $=-.107 ; \mathrm{p} \leq .05)$.

\section{Discussion}

The great majority of climbers in the sample were males $(86.5 \%$; $n=721)$, only a small portion being female $(13.5 \% ; n=113)$. Over half $(51.6 \%)$ of the respondents indicated that they were between 21 and 40 years old. The sample of climbers on Mt. Hood and Mt. Baker were highly educated, with over $44 \%$ 
reporting that they had earned a Bachelor's degree. Overall, the climbers were predominantly middleaged, well-educated, white males.

The findings from this study showed that climbers on Mt. Hood and Mt. Baker exhibited high levels of intrinsic motivation, rather than extrinsic social motivations, to participate in mountaineering. This supports the previous notion that leisure tends to be intrinsically motivated (Iso-Ahola 1980) and linked to a variety of internal motives (Delle Fave et al. 2003; Ewert et al. 2013). In other words, climbers are more influenced by internal rewards (e. g. raised self-esteem or confidence), as well as social and environmental factors. Overall, motives from the physical setting domain (to be outdoors and to view scenery) were rated highest by climbers, followed by catharsis motives (to get away from my daily routine) and challenge / risk motives (to feel a sense of accomplishment). This suggests that climbers derive important emotional benefits from mountaineering, and that this activity is a way to achieve personal goals or desired outcomes while recreating in an alpine wilderness setting. Climbers also considered it very important to develop their skills, suggesting that they climb, in part, to develop a sense of control. The high level of importance placed by climbers on skills and abilities is to be expected, given the extreme nature of mountaineering and the risks involved with this activity.

It was interesting to see that, overall, motivations to be known as a mountaineer and to climb a new route were not important to the sample of climbers. Perhaps this has to do with the ease of access and the time required to summit both Mt. Hood and Mt. Baker. Past mountaineering studies have looked at climbers on more arduous, remote peaks like Mt. McKinley (Ewert 1994), or those with more restricted access like Mt. Rainer (Ewert 1985). Certainly, those who climb mountains like Mt. McKinley or other high alpine peaks are taking on a greater mountaineering endeavour and may place greater importance on motives that are of greater specificity to the activity. This type of climber may have advanced levels of skill and place higher levels of importance on motives for self-image, sensation-seeking, or the pursuit of new challenges in adventure settings (Ewert et al. 2013).

The items were examined for differences between motivations on Mt. Baker and Mt. Hood, as suggested by previous studies (Ewert 1990, 1994; Smith et al. 2016). Statistically significant differences were found in six of the 22 mountaineering motivations. The results showed that Catharsis, Recognition and Creativity domain items were more important on Mt. Baker than on Mt. Hood. The item with the most significant mean difference between the two mountains was to be known as a mountaineer $(\mathrm{p} \leq .001)$. The climbers on Mt. Baker (mean $=2.22$ ) rated this item as significantly more important than those who climbed on Mt. Hood (mean $=1.96$ ), but both groups rated it low in general. While there are several beginner and interme- diate routes on Mt. Baker, climbs on this mountain are generally longer in duration and greater in terms of vertical metres. Mt. Baker generally takes two days to summit and requires climbers to trek over longer approaches, especially in comparison to the South Side route on Mt. Hood, where climbers start out at about 1800 metres. Therefore, an ascent on Mt. Baker may give a climber a greater sense of recognition, which ultimately leads to a greater sense of reputation amongst peers and a stronger sense of belonging in the mountaineering community.

The results also show that the climbers on Mt. Baker accord greater importance to cathartic motivations. For these climbers, Catharsis motivations, such as to slow your mind (mean $=3.60$ ) and to relieve stress and anxiety (mean $=3.79)$, were significantly more important than for climbers on Mt. Hood. Climbers on Mt. Baker also rated the Physical Setting item to be outdoors (mean $=4.66$ ) with greater importance than those on Mt. Hood. The results of the analysis suggest that climbers on Mt. Baker are seeking a greater opportunity for stress relief and a more relaxing experience than those on Mt. Hood. The geographic location of the mountain itself helps to support this claim. Mt. Baker lies approximately 114 miles from downtown Seattle, Washington, on the northernmost edge of the Mt. Baker-Snoqualmie National Forest. The South Side approach on Mt. Hood lies approximately 62 miles from downtown Portland, Oregon. Considering this proximity, those seeking cathartic outdoor opportunities may have a stronger inclination to pursue a climbing experience on Mt. Baker rather than on Mt. Hood. Mt. Hood also has a higher variety and density of recreational activities taking place directly on the mountain. Timberline and Mt. Hood Meadows are both popular ski resorts that cover portions of the actual mountain. Climbers often interact with high volumes of skiers, snowboarders and sightseers until they reach altitudes above the Palmer Glacier and enter the Mt. Hood Wilderness. Even then, the resort lights and chairlifts are still highly noticeable. Mt. Baker's ski areas are located on adjacent mountains, and therefore climbers see substantially less development and permanent human impact during their mountaineering experience. This may give climbers on Mt. Baker a greater sense of escape and stress relief than climbers at Mt. Hood.

The findings of this study suggest that climbers on Mt. Baker have somewhat different motives for mountaineering than climbers on Mt. Hood. Previous studies have suggested that differences in motives may be influenced by differences in a climber's experience or skill level (Ewert 1985, 1994; Ewert et al. 2013; Schreyer \& Lime 1984). Less experienced climbers placed more motivational importance on escaping from normal life, developing climbing skills, recognition and social activities (Ewert 1994). Conversely, highly experienced climbers placed more motivational importance on exhilaration, challenge, helping oth- 
ers, making decisions and locus of control than either the intermediate or the beginner-level climbers. While this study did not examine motivational differences by skill or experience level, climbers on Mt. Baker placed higher motivational importance on Catharsis, Recognition and Physical Setting items. Thus, it is possible that the Mt. Baker climbers may be less experienced than the Mt. Hood climbers.

The regression analysis showed an overall weak relationship between motivations and participation (Adjusted R Square $=0.142, \mathrm{p} \leq .001$ ). However, seven motives, most notably the locus of control motives (to form new friendships, to gain control of the situation and to develop skills), were significant predictors of mountaineering participation at Mt. Hood and Mt. Baker. This finding is consistent with previous studies showing that control and camaraderie-strengthening are important motives for participation (Buckley 2012; Pomfret 2011). In future studies, other variables, such as a visitor's perception of the level of crowding or satisfaction, may be more critical predictors of participation (Burns et al. 2003; Burns \& Graefe 2007).

Finally, this study showed us that mountain climbers are unique, highly motivated recreationists who seek thrilling experiences in high alpine settings. They seek these experiences regardless of the potential risks and dangers that go along with climbing in a particularly hostile environment. These findings are similar to those of Hibner et al. (2018) and Muhar et al. (2007). The motivations and perspectives of mountain tourists, whether climbing or tourism, can have major consequences on our mountains, and need to be understood.

\section{Conclusion}

This study suggested that the primary motivations of the climbers on Mt. Hood and Mt. Baker were those that focused on the aesthetic quality of the two locations, as well as the opportunity to be in nature. The findings also showed that climbers displayed different motivations in different alpine wilderness settings. Climbers on Mt. Baker were more motivated than Mt. Hood climbers by receipt of recognition, stress relief, physical exercise and thinking about new ways to approach a climb. Moreover, the motivations of these mountain visitors are in line with the mandate in the Wilderness Act to protect the unique experiences that are possible in wilderness areas. The results of this study offer an initial understanding of who the climbers are and what motivates them to scale the two peaks. These climbers seek an experience that is characterized by a particular mountain setting and its alpine resources. This type of information can assist in adapting or creating management policies that further enhance a sustainable mountaineering experience on both peaks.

\section{References}

Barnett, A. 2004. Displacement and coping at wilderness climbing destinations: A survey of mountaineers in Washington and Oregon. Thesis submitted for publication. University of Idaho.

Borrie, W.T., S.L. Pohl, \& M.E. Patterson 2000. Women, wilderness, and everyday life: A documentation of the connection between wilderness recreation and women's everyday lives. Journal of Leisure Research 32(4): 415-434.

Bowley, G. 2011. No way down: life and death on K2. New York, NY.

Breed, A.G. \& B. Gurubacharya 2016. Did Everest climber Sharp have to die? Available at: http:/ /www.washingtonpost.com/wpdyn/content/ article/2006/07/16/AR2006071600309_pf.html.

Buckley, R. 2012. Rush as a key motivation in skilled adventure tourism: Resolving the risk recreation paradox. Tourism Management 33: 961-970.

Bultena, G.L. \& M.J. Taves 1961. Changes in wilderness images and forestry policy. Journal of Forestry 59(3): 167-171.

Burns, R.C. \& A. Graefe 2007. Constraints to outdoor recreation in Pacific Northwest national forests: Exploring perceptions of respondents whose households include persons with disabilities. Journal of Leisure Research 39(1): 156-181.

Burns, R.C., A.R. Graefe, A.R. \& J. Absher 2003. Alternate measurement approaches to recreational customer satisfaction: Performance-only and importance-performance gap scores. Leisure Sciences 25(4): 363-380.

Chuprinko, T.L. 2012. Mountaineering motivations and perceived crowding: An examination of climbers on Mt. Baker, Washington and Mt. Hood, Oregon. Unpublished Master's Thesis, West Virginia University.

Covelli, E.L. 2006. Using the paradigm of constraints to understand non-traditional forest recreation use: Racial and ethnic minorities' participation rates. Unpublished Master's Thesis, West Virginia University.

Delle Fave, A., M. Bassi \& F. Massimini 2003. Quality of experience and risk perception in high-altitude rock climbing. Journal of Applied Sport Psychology 15: 82-98.

Dillman, D.A., J.D. Smyth \& L.M. Christian 2014. Internet, phone, mail, and mixed-mode surveys: The tailored design method.

Driver, B.L. 1983. Master list of items for Recreation Experience Preference scales and domains. Unpublished document. USDA Forest Service, Fort Collins, CO: Rocky Mountain Forest and Range Experimentation.

Driver, B. \& R. Toucher 1970. Toward a behavioral interpretation of recreational engagements, with implications for planning. Elements of Outdoor Recreation Planning. University Microfilms: 9-31. Ann Arbor, MI.

Ewert, A.W. 1985. Why people climb: The relationship of participant motives and experience level 
to mountaineering. Journal of Leisure Research 17(3): 241-250.

Ewert, A.W. 1987. Research in outdoor adventure: Overview and analysis. The Bradford Papers Annual 2: 15-28.

Ewert, A.W. \& S. Hollenhorst 1989. Testing the adventure model: Empirical support for a model of risk recreation participation. Journal of Leisure Research 21: 124-139.

Ewert, A.W. 1990. Mount St. Helens: A case study of managing for change in wildland recreation. Environmental Management 14(2): 179-184.

Ewert, A.W. 1994. Playing the edge: Motivation and risk-taking in a high-altitude wilderness-like environment. Environment and Behavior 26: 3-24.

Ewert, A.W., K. Gilbertson, Y. Luo \& A. Voight 2013. Beyond "because it's there": Motivations for pursuing adventure recreational activities. Journal of Leisure Research 45(1): 91-111.

Ewert, A.W. \& F. Vernon 2013. Outdoor and adventure recreation. In Human Kinetics (ed.), Introduction to recreation and leisure ( $\left.2^{\text {nd }} \mathrm{ed}.\right)$ : 321-340. Champaign, IL.

Fluker, M.R. \& L.W. Turner 2000. Needs, motivations and expectations of a commercial whitewater rafting experience. Journal of Travel Research 38: 380 389.

Frissel, S. \& G. Stankey 1972. Wilderness environmental quality: Search for social and ecological harmony. Proceedings of the Society of American Foresters Annual Conference, Society of American Foresters: 170-183. Hot Springs, AR.

Garms, M., P. Fredman \& I. Mose 2017. Travel motives of German tourists in the Scandinavian mountains: The case of Fulufjället National Park. Scandinavian Journal of Hospitality and Tourism 17(3): 239-258.

Graefe, A.R., B. Thapa, J.J. Confer \& J.D. Absher 2000. Relationships between trip motivations and selected variables among Allegheny National Forest visitors. USDA Forest Service Proceedings RMRS-P-15 4: 107-113.

Hibner, J.K., A. Taczanowska, C. Zieba, A. Brandenburg, A. Muhar \& J. Balon 2018. Visitor profiling for cable car mountain destinations as a basis for protected area management: A case study of the summer season in the Tatra Mountains at Kasprowy Wierch (Poland) and Skalnaté Pleso (Slovakia). eco.mont - Journal on protected mountain areas research and management 10(1): 24-35.

Iso-Ahola, S.E. 1980. The social psychology of leisure and recreation. Dubuque, Iowa.

Kiewa, J. 2001. Control over self and space in rock climbing. Journal of Leisure Research 33: 363-382.

Knopf, R.C., G.L. Peterson \& E.C. Leatherberry 1983. Motives for recreational river floating: Relative consistency across settings. Leisure Sciences 5(3): 231255.

Kocis, S.M., D.B. K English, S.J. Zarnoch, R. Arnold, L. Warren \& C. Ruka 2004. National visitor use monitoring results: Mount Hood
National Forest. Available at: http://www.fs.fed.us/ recreation/programs/nvum/reports/year4/R6_F6_ mounthood_final.htm (accessed: 14/01/2019).

Manfredo, M.J., B.L. Driver \& M.A. Tarrant 1996. Measuring leisure motivation: A meta-analysis of the recreation experience preference scales. Journal of Leisure Research 28(3): 188-213.

Manning, R.E. 1999. Studies in outdoor recreation: Search and research for satisfaction. Corvallis, OR.

Manning, R.E. 2001. Programs that work visitor experience and resource protection: A Framework for managing the carrying capacity of National Parks. Journal of Park and Recreation Administration 19(1): 93-108.

Manning, R.E. 2007. Parks and carrying capacity: Commons without Tragedy. Washington D.C.

Maslow, A.H. 1943. A theory of human motivation. Psychological Review 50: 370-396.

Mei-Dan, O., E. Monasterio, M. Carmont \& A. Westman 2013. Fatalities in wingsuit BASE jumping. Wilderness \& Environmental Medicine 24: 321-327. DOI: 10.1016/j.wem.2013.06.010

Metcalf, E., A. Graefe, N. Trauntvein \& R.C. Burns 2015. Understanding hunting constraints and negotiation strategies: A typology of female hunters. Human Dimensions of Wildlife 20(1): 1-17.

Monasterio, E. \& C.R. Cloninger 2019. Self-Transcendence in Mountaineering and BASE Jumping. Frontiers in Psychology. DOI: 10.3389/fpsyg.2018.02686

Muhar, A., T. Schauppenlehner, C. Brandenburg \& A. Arnberger 2007. Alpine summer tourism: the mountaineers' perspective and consequences for tourism strategies in Austria. Forest Snow Landscape Research 81(1/2): 7-17.

Outdoor Industry Foundation 2018. Outdoor Recreation Participation Report, 2018. Boulder, CO.

Pomfret, G.P. 2006. Mountaineering adventure tourists: A Conceptual framework for research. Tourism Management 27: 113-123.

Pomfret, G.P. 2011. Package mountaineer tourists holidaying in the French Alps: An evaluation of key influences encouraging their participation. Tourism Management 32(3): 501-510.

Raadik, J., S.P. Cottrell, P. Fredman, P. Ritter \& P. Newman 2010. Understanding recreational experience preferences: Application at Fulufjället National Park, Sweden. Scandinavian Journal of Hospitality and Tourism 10(3): 231-247.DOI: 10.1080/15022250.2010.486264.

Roggenbuck, J.R., \& B.L. Driver 2000. Benefits of nonfacilitated uses of wilderness. In: McCool, S.F., D.N. Cole, W.T. Borrie, \& J. O'Loughlin (eds.), Wilderness Science in a Time of Change Conference. Wilderness as a place for scientific inquiry. Proceedings RMRS-P-15-VOL-3. USDA Forest Service, Rocky Mountain Research Station, Fort Collins, Colorado, USA 3: 33-49.

Ryan, R.M. \& E.L. Deci 2000. Intrinsic and extrinsic motivations: Classic definitions and new directions. Contemporary Educational Psychology 25: 54-67.

Schreyer, R. \& D.W. Lime 1984. A Novice isn't necessarily a novice: The Influence of experience use his- 
tory on subjective perceptions of recreation participation. Leisure Sciences 6(2): 131-149.

Smith, N., F. Kinnafick, S.J. Cooley \& G.M. Sandal 2016. Reported growth following mountaineering expeditions: The role of personality and perceived stress. Environment and Behavior 49(8): 933-955.

Stankey, G.H. \& R. Schreyer 1987. Attitudes toward wilderness and factors affecting visitor behavior. In: Lucas, R.C. (ed.), Proceedings: National Wilderness Research Conference: Issues, State-of-Knowledge, Future Directions. General Technical Report INT-220. USDA Forest Service, Intermountain Research Station, Ogden, Utah, USA.

USDA 2019. United States Department of Agriculture. Available at: https://www.fs.usda.gov/mthood (accessed: 14/01/2019).

US Forest Service 2006. National visitor use monitoring results for Mt. Baker-Snoqualmie National Forest. Available at: http://apps. fs.usda.gov/nrm/nvum/results / Forest.aspx/ Home?Forest $=$ A06005\&Round $=2 \quad$ (accessed: 14/01/2019)

Will, K. 2016. Wilderness Recreation: An analysis of social carrying capacity, regional differences, and the role of gender. Unpublished Master's Thesis, West Virginia University.
Williams, P. \& G. Soutar 2005. Close to the „edge“: critical issues for adventure tourism operators. Asia Pacific Journal of Tourism Research 10(3): 247-261.

\section{Authors}

Robert C. Burns

is a Professor and Director of the West Virginia University Division of Forestry and Natural Resources. Professor and Director, E-mail: Robert.Burns@ mail.wvu.edu

\section{Teri Chuprinko}

earned her M.S. in Recreation, Parks and Tourism Resources from West Virginia University. School of Public Health. West Virginia University. E-mail: Teri. chuprinko@hsc.wvu.edu

\section{Mary E. Allen'}

is a Postdoctoral Research Associate at West Virginia University's Division of Forestry and Natural Resources. E-mail: mary.allen1@mail.wvu.edu

${ }^{1}$ Division of Forestry and Natural Resources, West Virginia University, Morgantown, WV, USA. 